OPEN ACCESS

Edited by:

Erik Maquoi,

University of Liège, Belgium

Reviewed by:

Achilleas D. Theocharis,

University of Patras, Greece

Christian Stock,

University of Münster, Germany

*Correspondence:

Sylvie Brassart-Pasco

sylvie.brassart-pasco@univ-reims.fr

Specialty section:

This article was submitted to Molecular and Cellular Oncology,

a section of the journal

Frontiers in Oncology

Received: 16 January 2020 Accepted: 05 March 2020

Published: 15 April 2020

Citation

Brassart-Pasco S, Brézillon S, Brassart B, Ramont L, Oudart J-B and

Monboisse JC (2020) Tumor Microenvironment: Extracellular Matrix

Alterations Influence Tumor

Progression. Front. Oncol. 10:397. doi: 10.3389/fonc.2020.00397

\section{Tumor Microenvironment: Extracellular Matrix Alterations Influence Tumor Progression}

\author{
Sylvie Brassart-Pasco ${ }^{1,2 *}$, Stéphane Brézillon ${ }^{1,2}$, Bertrand Brassart ${ }^{1,2}$, Laurent Ramont ${ }^{1,2,3}$ \\ Jean-Baptiste Oudart ${ }^{1,2,3}$ and Jean Claude Monboisse ${ }^{1,2,3}$ \\ ${ }^{1}$ Université de Reims Champagne Ardenne, SFR CAP-Santé (FED 4231), Laboratoire de Biochimie Médicale et Biologie \\ Moléculaire, Reims, France, ${ }^{2}$ CNRS UMR 7369, Matrice Extracellulaire et Dynamique Cellulaire - MEDyC, Reims, France, \\ ${ }^{3} \mathrm{CHU}$ Reims, Service Biochimie-Pharmacologie-Toxicologie, Reims, France
}

The tumor microenvironment (TME) is composed of various cell types embedded in an altered extracellular matrix (ECM). ECM not only serves as a support for tumor cell but also regulates cell-cell or cell-matrix cross-talks. Alterations in ECM may be induced by hypoxia and acidosis, by oxygen free radicals generated by infiltrating inflammatory cells or by tumor- or stromal cell-secreted proteases. A poorer diagnosis for patients is often associated with ECM alterations. Tumor ECM proteome, also named cancer matrisome, is strongly altered, and different ECM protein signatures may be defined to serve as prognostic biomarkers. Collagen network reorganization facilitates tumor cell invasion. Proteoglycan expression and location are modified in the TME and affect cell invasion and metastatic dissemination. ECM macromolecule degradation by proteases may induce the release of angiogenic growth factors but also the release of proteoglycan-derived or ECM protein fragments, named matrikines or matricryptins. This review will focus on current knowledge and new insights in ECM alterations, degradation, and reticulation through cross-linking enzymes and on the role of ECM fragments in the control of cancer progression and their potential use as biomarkers in cancer diagnosis and prognosis.

Keywords: cancer, microenvironment, extracellular matrix, matrikines, integrins, proteases

\section{INTRODUCTION}

The tumor microenvironment (TME) is a complex structure composed of a large variety of cell types embedded in a modified extracellular matrix (ECM), with bidirectional communication between cells and ECM macromolecules to determine tumor progression and metastatic dissemination. The communication may involve cell-cell contacts but may also be controlled by intact ECM macromolecules or by several of their domains released by limited proteolysis and called matrikines or matricryptins. In this review, we will focus on ECM alterations occurring in TME, on the role of released matrikines in the control of cancer progression, and on the potential use of ECM fragments as biomarkers for cancer diagnosis and prognosis. 


\section{TUMOR MICROENVIRONMENT: AN ACTIVE PLAYER IN CANCER PROGRESSION}

Tumors are diverse by the nature of their TME composition, stromal cell proportion, and activation states. TME undergoes transformations during tumor progression as a result of tissue remodeling. TME comprises a wide variety of cell types such as fibroblasts, endothelial cells, pericytes, and immune and inflammatory cells. These different cells elicit cross-talks leading to cell activation and differentiation and alterations in ECM structural and biological properties facilitating tumor cell proliferation, invasion, and metastatic dissemination. Within the TME, different $\mathrm{T}$ cell and $\mathrm{B}$ cell populations infiltrate invasive tumors and draining lymphoid organs (1). Tumorassociated macrophages (TAMs) are either tissue-resident or derived from bone marrow or spleen and play an important role in tumorigenesis regulation by facilitating cell migration, invasion, and metastasis (2). Tumor cells lead to the recruitment of neutrophils in tumorigenesis sites by secreting chemokines and interleukin (IL)-8. Infiltration by neutrophils appears to confer a poor prognosis (3). A dominant cellular component is fibroblasts that exert a key role in cancer progression and metastasis. Fibroblasts are usually quiescent and become activated to differentiate into myofibroblasts, also called cancerassociated fibroblasts (CAFs) (4). The main progenitors of CAFs come from resident fibroblasts, but CAFs can also come from smooth muscle cells, pericytes, or from bone marrow-derived mesenchymal cells leading to a heterogeneous cell population (5-7). Growth factors, secreted by tumor cells and infiltrating immune cells, largely govern stromal fibroblast recruitment. Transforming growth factor (TGF) $\beta$, platelet-derived growth factor (PDGF), and fibroblast growth factor (FGF) 2 are key mediators of fibroblast activation. CAFs become synthetic machines that produce TME components creating an ECM structure as well as metabolic and immune reprogramming of TME. CAF secretome includes growth factors [epidermal growth factor (EGF), bone morphogenetic protein (BMP), FGF, or TGFB] and some chemokines such as C$\mathrm{X}-\mathrm{C}$ motif ligand (CXCL)12 or stroma-derived factor (SDF)1 , which recruit circulating endothelial progenitor cells (4). These soluble factors, in conjunction with the angiogenic switch and several miRNAs, stimulate endothelial cells and their associated pericytes to develop tumor angiogenesis or lymphangiogenesis (2).

\footnotetext{
Abbreviations: ADAMTS, a disintegrin and metalloproteinase with thrombospondin motifs; BMP, bone morphogenetic protein; CAF, cancerassociated fibroblast; ECM, extracellular matrix; ERC, elastin receptor complex; FGF, fibroblast growth factor; 4E-BP1 protein, eukaryotic initiation factor 4E-binding protein 1; HER2, human epidermal growth factor receptor-2; LN, laminin; LOX, lysyl oxidase; MMP, matrix metalloproteinase; mTOR, mammalian target of rapamycin; PDGF, platelet-derived growth factor; ROS, reactive oxygen species; SDF 1, stroma-derived factor 1; SSTN, synstatin; sVEGFR1, soluble VEGF tyrosine kinase receptor 1; TAM, tumor-associated macrophage; TGF $\beta$, transforming growth factor $\beta$; TME, tumor microenvironment.
}

\section{METABOLIC ALTERATIONS IN THE TUMOR MICROENVIRONMENT}

During the local growth of tumor, the surrounding vessels fail to meet the high demand of oxygen leading to hypoxic areas within the tumor and TME (8). Prolyl-hydroxylases are responsible for the labeling of hypoxia-inducible factors (HIFs) to be degraded by $26 \mathrm{~S}$ proteasome. Under hypoxic conditions, prolyl-hydroxylases are inhibited, leading to the stabilization of HIFs that induces the expression of various genes implicated in tumor progression. Moreover, hypoxic responses include the unfolded protein response (UPR) and mammalian target of rapamycin (mTOR) signaling (9). mTOR signaling, through the phosphoinositide 3-kinase (PI3K)/Akt pathway, largely contributes to the regulation of cell survival, growth, and metabolism through phosphorylation of the eukaryotic initiation factor 4E-binding protein 1 (4E-BP1 protein) and ribosomal protein S6 kinase (10). HIF-1 is also a key regulator of the metabolic switch. By inducing specific gene expression, it alters the cellular metabolism, increasing glycolysis and lactate production $(11,12)$. Lactate arises from glycolysis which takes place under hypoxic conditions, but in tumors, glycolysis can also take place in oxygenated areas (8).

Nicotinamide adenine dinucleotide phosphate (NADPH) oxidase of inflammatory cells generates oxidative stress. Superoxide ions are converted into hypochlorous acid ( $\mathrm{HOCl})$ by myeloperoxidase and into $\mathrm{OH}^{\bullet}$ radicals. Tumor cells with a high metabolism also release reactive oxygen species (ROS) and promoted ROS production in CAFs. ROS induce oxidative stress in TME and activate HIF-1 and nuclear factor (NF)- $\mathrm{\kappa B}$ pathways, leading to an increase in autophagy (7). ROS also induce strong alterations in DNA, cell membrane, and ECM components. For example, collagen I is partially degraded by ROS and becomes more susceptible to proteolytic cleavage (13). Among proteases, neutrophils or TAMs secrete matrix metalloproteinase (MMP)-8 and-9 as well as neutrophil elastase that collaborates with CAF-secreted proteases to degrade ECM.

Main metabolic alterations of TME are summarized in Figure 1.

\section{EXTRACELLULAR MATRIX ALTERATIONS IN THE TUMOR MICROENVIRONMENT}

Another important feature of TME is the composition and organization of ECM, whose mechanical properties affect cell behavior. The ECM is mainly secreted by CAFs which produce more ECM proteins than normal fibroblasts. It is composed of various macromolecules including collagens, glycoproteins (fibronectin and laminins), proteoglycans, and polysaccharides with different physical and biological properties. Interstitial matrix, primarily synthesized by stromal cells, is rich in fibrillar collagens and proteoglycans. CAF secretome analyses show an increased secretion of bone morphogenetic protein (BMP)1, thrombospondin-1, and elastin interface $2(7,14)$. Several splice variants of fibronectin ED-A and ED-B and tenascins $\mathrm{C}$ and $\mathrm{W}$ may be secreted by CAFs (15). Interstitial ECM is highly 


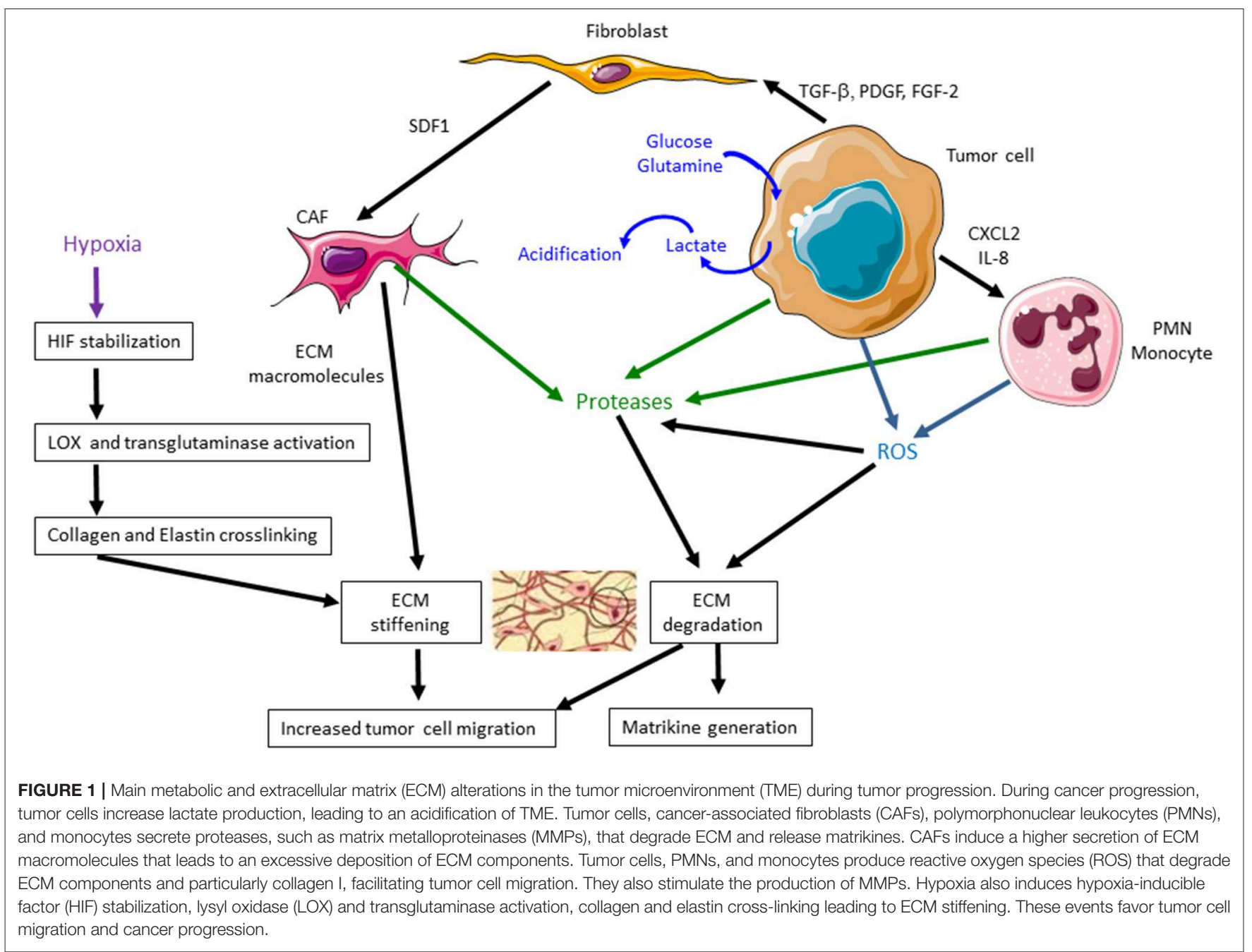

charged and hydrated and greatly participates in the tensile strength of tissues. Stiffness of neoplastic tumors is strongly higher than adjacent normal tissues. Cancer cells, CAFs, and TAMs, stimulated by hypoxia, modulate together ECM within the TME through an excessive deposition of structural components such as collagens, as well as cross-linking enzymes of the lysyl oxidase (LOX) and transglutaminase families, particularly LOX-1, LOXL-2, and transglutaminase-2 (16, 17). Collagen and elastin fibers are reoriented and cross-linked by LOX and transglutaminase, resulting in larger and more rigid fibrils that facilitate cell migration $(18,19)$. Figure 1 summarizes the main ECM alterations in TME.

\section{EXTRACELLULAR MATRIX BREAKDOWN BY MIGRATING CANCER CELLS}

A decisive hallmark in cancer progression is the crossing of ECM and basement membrane (BM) by cancer cells. To penetrate the ECM, cancer cells secrete a number of proteolytic enzymes of the MMP family. BMs are specialized ECMs which are more compact and less porous. They present a distinct composition with collagen IV and laminin interconnected networks and proteoglycans such as perlecan. Several other types of collagen are associated to the BM, collagens XV, XVIII, and XIX. During ECM-barrier crossing, proteases release soluble and active fragments referenced in Table 1, called matrikines or matricryptins which may control cancer progression.

\section{EXTRACELLULAR MATRIX-DERIVED FRAGMENTS INFLUENCE TUMOR PROGRESSION}

The different matrikines derived from ECM macromolecules, collagens, glycoproteins, or proteoglycans may exert either pro- or anti-tumorigenic properties in various cancer models (Table 1). We and others demonstrated that collagen IVderived matrikines (canstatin, tumstatin, and tetrastatin) and collagen XIX-derived matrikine act through binding to $\alpha 3 \beta 1$, $\alpha 5 \beta 1$, or $\alpha \mathrm{V} \beta 3$ integrins. The binding elicits an inhibition of 
TABLE 1 | ECM fragments affect the main hallmarks of cancer progression.

\begin{tabular}{|c|c|c|c|c|}
\hline ECM bioactive fragments & Parent molecule & Generating enzymes & Receptors & Biological activity \\
\hline \multicolumn{5}{|l|}{ Collagen fragments } \\
\hline Type IIB procollagen $\mathrm{NH} 2$ propeptide & Type IIB collagen & ADAMTS-3 (20) & $\alpha \vee \beta 3, \alpha \vee \beta 5$ integrins (21) & $\begin{array}{l}\nearrow \mathrm{EC} \text { and tumor cell death (chondrosarcoma, } \\
\text { cervical and breast cancer) (21) through } \\
\text { programmed cell necrosis (22) }\end{array}$ \\
\hline Arresten ( $\alpha 1$ chain NC1 domain) & Type IV collagen & $\begin{array}{l}\text { Cathepsin S (23) } \\
\text { MT1-MMP, } \\
\text { MT2-MMP (24) }\end{array}$ & $\alpha 1 \beta 1$ integrin $(25,26)$ & $\begin{array}{l}\searrow \text { Angiogenesis and tumor growth (melanoma, } \\
\text { glioblastoma, colorectal and lung cancer, } \\
\text { squamous cell carcinomas) (25) } \\
\searrow \text { FAK/c-Raf/MEK-1/2/ERK-1/2/p38 MAPK } \\
\text { pathways in EC } \\
\nearrow \text { EC apoptosis through bcl-x//bax ratio } \\
\text { modulation (25) }\end{array}$ \\
\hline Canstatin ( $\alpha 2$ chain NC1 domain) & Type IV collagen & $\begin{array}{l}\text { Cathepsin S (23) } \\
\text { MT1-MMP, } \\
\text { MT2-MMP (24) }\end{array}$ & $\begin{array}{l}\alpha 1 \beta 1, \alpha \vee \beta 3, \alpha \vee \beta 5 \text { integrins } \\
(27)\end{array}$ & $\begin{array}{l}\searrow \text { Angiogenesis and tumor growth (ocular, } \\
\text { lung, breast, oral squamous cell, esophageal } \\
\text { carcinoma, gastric, ovarian, pancreatic, } \\
\text { prostate, and colorectal cancer (28) } \\
\searrow \text { VEGF-AVEGFR-1-2 signaling pathway in } \\
\text { squamous cell carcinoma (29) } \\
\nearrow \text { Apoptosis in cancer cell and EC through } \\
\text { bcl-2bcl-xV/bax ratio modulation (30) } \\
\searrow \text { Caspase } 8 \text { and } 9 \text { activation in EC (27) }\end{array}$ \\
\hline Tumstatin ( $\alpha 3$ chain NC1 domain) & Type IV collagen & MMP-9 (31) & $\alpha \vee \beta 3, \alpha \vee \beta 5$ integrins (32) & $\begin{array}{l}\searrow \text { Angiogenesis and tumor growth (melanoma, } \\
\text { glioma, osteosarcoma, breast, colon, prostate } \\
\text { and lung cancer, gastric, hepatocellular, and } \\
\text { squamous cell carcinoma }(33,34)\end{array}$ \\
\hline 54-132 amino-acid sequence & & & & $\begin{array}{l}\text { 54-132 amino-acid sequence: } \nearrow \text { G1 arrest, } \nearrow \\
\text { caspase-3 activation and } \searrow \\
\text { FAK/PI3K/Akt/mTOR pathway in ECs (35) }\end{array}$ \\
\hline 185-203 amino-acid sequence & & & & $\begin{array}{l}\text { 185-203 amino-acid sequence }: \searrow \text { melanoma } \\
\text { and EC migration through a decrease in } \\
\text { MMP-2, UPA, t-PA (36) }\end{array}$ \\
\hline Tetrastatin ( $\alpha 4$ chain NC1 domain) & Type IV collagen & & $\alpha \vee \beta 3$ integrin (37) & $\begin{array}{l}\searrow \text { Tumor growth (melanoma, glioma, } \\
\text { osteosarcoma, breast, colon, prostate and lung } \\
\text { cancer, gastric, hepatocellular and squamous } \\
\text { cell carcinoma (37-40) } \\
\searrow \text { FAK/PI3K/Akt pathway and } \searrow \text { MMP-2 in } \\
\text { tumor cells }(37,38)\end{array}$ \\
\hline Lamstatin ( $\alpha 5$ chain NC1 domain) & Type IV collagen & & & $\begin{array}{l}\searrow \text { Angiogenesis (41) and lung cancer growth } \\
(42,43) \\
\text { Unknown molecular mechanism }\end{array}$ \\
\hline Hexastatin ( $\alpha 6$ chain NC1 domain) & Type IV collagen & & & $\begin{array}{l}\searrow \text { Angiogenesis and tumor growth (Lewis } \\
\text { lung carcinoma and spontaneous pancreatic } \\
\text { insulinoma) (44) } \\
\text { Unknown molecular mechanism }\end{array}$ \\
\hline $\begin{array}{l}\text { Vastatin (NC1 domain of collagen VIII } \\
\text { alpha } 1 \text { chain) }\end{array}$ & Type VIII collagen & & & $\begin{array}{l}\searrow E C \text { proliferation and tumor growth and } \\
\text { metastasis in murine hepatocellular carcinoma } \\
\text { models }(45) \\
\searrow \text { PCK1, JAG2, and C-Fos, \Notch/AP-1 } \\
\text { pathway (46) }\end{array}$ \\
\hline Restin (NC10 domain of collagen XV) & Type XV collagen & & & $\begin{array}{l}\searrow \text { EC migration, renal carcinoma growth (47) } \\
\text { and breast cancer metastasis (48) } \\
\searrow \text { ATF3 activity by direct interaction (49) } \\
\searrow \text { EMT through } \mathrm{p}-73 \text { binding, mir-200a/b } \\
\text { increase and ZEB1/2 inhibition in breast cancer } \\
\text { cells (48) }\end{array}$ \\
\hline $\begin{array}{l}\text { Endostatin (20-kDa C-terminal } \\
\text { fragment of collagen XVIII) }\end{array}$ & Type XVIII collagen & & $\alpha 5 \beta 1$ integrin; caveolin-1 (50) & $\begin{array}{l}\searrow \text { Angiogenesis, lymphangiogenesis and tumor } \\
\text { growth (51) } \\
\nearrow \text { Src-kinase pathway, \ RhoA GTPase } \\
\text { activity; \Ras/c-Raf/p38/Erk-1 pathway in EC } \\
(52,53)\end{array}$ \\
\hline
\end{tabular}


TABLE 1 | Continued

\section{ECM bioactive fragments}

NC1 XIX

\section{Elastin fragments}

VG-6 (VGVAPG)

AG-9 (AGVPGLGVG)

\section{Laminin fragments}

IKVAV ( $\alpha 1$ chain fragment)

\begin{abstract}
AG73 (RKRLQVQLSIRT from $\alpha 1$ chain)
YIGSR ( $\beta 1$ chain fragment)

C16 (KAFDITYVRLKF from $\gamma 1$ chain)

$\gamma 2$ chain $\mathrm{N}$-terminal fragment

$\alpha 3$ chain $\mathrm{C}$-terminal fragment

Laminin-111

Laminin-111

Laminin-111

Laminin 332
\end{abstract}

A5G27 (RLVSYNGIIFFLK from $\alpha 5$ chain) Laminin 511

\section{Fibronectin fragments}

Anastellin (type III module)

\section{Proteoglycans fragments}

Metastatin

Endorepellin

LG3 fragment (C-terminal fragment of

Endorepellin)

Fibronectin
Laminin-111

Type XIX collagen Plasmin (55)

Elastin

Elastin

MMP-2, cathepsin S, MT1-MMP (71)

Plasmin, MMP-2, MT1-MMP, C-proteinase, mTLD, BMP-1 (71)

Proteinase 3, epsin $G(58)$ MMP-7,9,12 (59) neprilysin (60)

$\alpha 3 \beta 1$ and $\alpha 6 \beta 1$ integrins (68)

Syndecans 1, 2, and 4 (68)

$67 \mathrm{KD}$ receptor (68)

$\alpha \vee \beta 3$ and $\alpha 5 \beta 1$ integrins (68)

$\alpha 3 \beta 1$ integrin, CD-44 (71)

$\alpha 3 \beta 1$ and $\alpha 6 \beta 1$ integrins (71)

Biological activity

Frizzled domain (FZC18): \Wnt/ $\beta$-catenin pathway (54)

$\searrow$ Melanoma cell migration, invasion, tumor growth and angiogenesis $(56,57)$

$\searrow$ MMP-14 (57) in melanoma

$\searrow$ FAK/PI3K/Akt/mTOR pathway in melanoma cells (57)

$\mathrm{ERC}, \alpha v \beta 3$ and $\alpha v \beta 5$ integrins, $\nearrow$ Angiogenesis (63) and tumor growth in melanoma models $(62,64,65)$

$\nearrow \mathrm{MT1}$-MMP, $\nearrow \mathrm{PI3K} / \mathrm{Akt} / \mathrm{NO}$ synthase, $\nearrow$ $\mathrm{NO} / \mathrm{cGMP} /$ Erk1/2 pathways in EC (66)

$\nearrow \mathrm{IL}-1 \beta$ through NF- $\kappa \mathrm{B}$ pathway in melanoma cell (67)

$\nearrow \mathrm{MMP}$ and plasminogen activation cascades in cancer cells

$\nearrow$ Tumor growth in a melanoma model (62)

$\nearrow$ Tumor cell migration, invasion through MMP

and plasminogen activation cascades

$\nearrow$ Angiogenesis, tumor growth, and metastasis (68)

$\nearrow$ bone marrow mesenchymal stem cell proliferation by activating MAPK/ERK $1 / 2$ and PI3K/Akt signaling pathways (69)

$\nearrow$ t-PA in melanoma cells (68)

$\nearrow$ Angiogenesis and tumor growth (68)

$\nearrow$ Rac1 and ERK1/2 signaling pathways (70)

$\searrow$ Tumor growth and metastasis (68)

Unknown mechanism

$\nearrow$ Tumor growth (68)

$\nearrow$ MMP-9 production in melanoma cells (68)

$\nearrow$ Angiogenesis, tumor growth and metastasis (71)

Unknown mechanism

$\nearrow$ Angiogenesis, tumor growth (71)

Unknown mechanism

$\searrow$ Breast tumor cell proliferation

$\nearrow$ 4T1.2 experimental pulmonary metastasis (72)

Unknown mechanism

$\searrow$ Angiogenesis, tumor growth and metastasis (73)

$\nearrow$ p38 MAPK activation in EC (74)

ADAMTS (75)

MMP-7 (77)

Cathepsin $L$ and

BMP-1-Tolloid-like

proteases (78) $\alpha 2 \beta 1$ integrin (79)

$\searrow$ Growth, migration, angiogenesis of melanoma and prostate cancer (76) Unknown mechanism

$\searrow$ EC proliferation and migration, angiogenesis, tumor growth (78-84)

$\searrow$ VEGF-ANEGFR pathway in EC (79)

$\nearrow$ autophagy through Peg3 activation in EC $(79,85)$ 
TABLE 1 | Continued

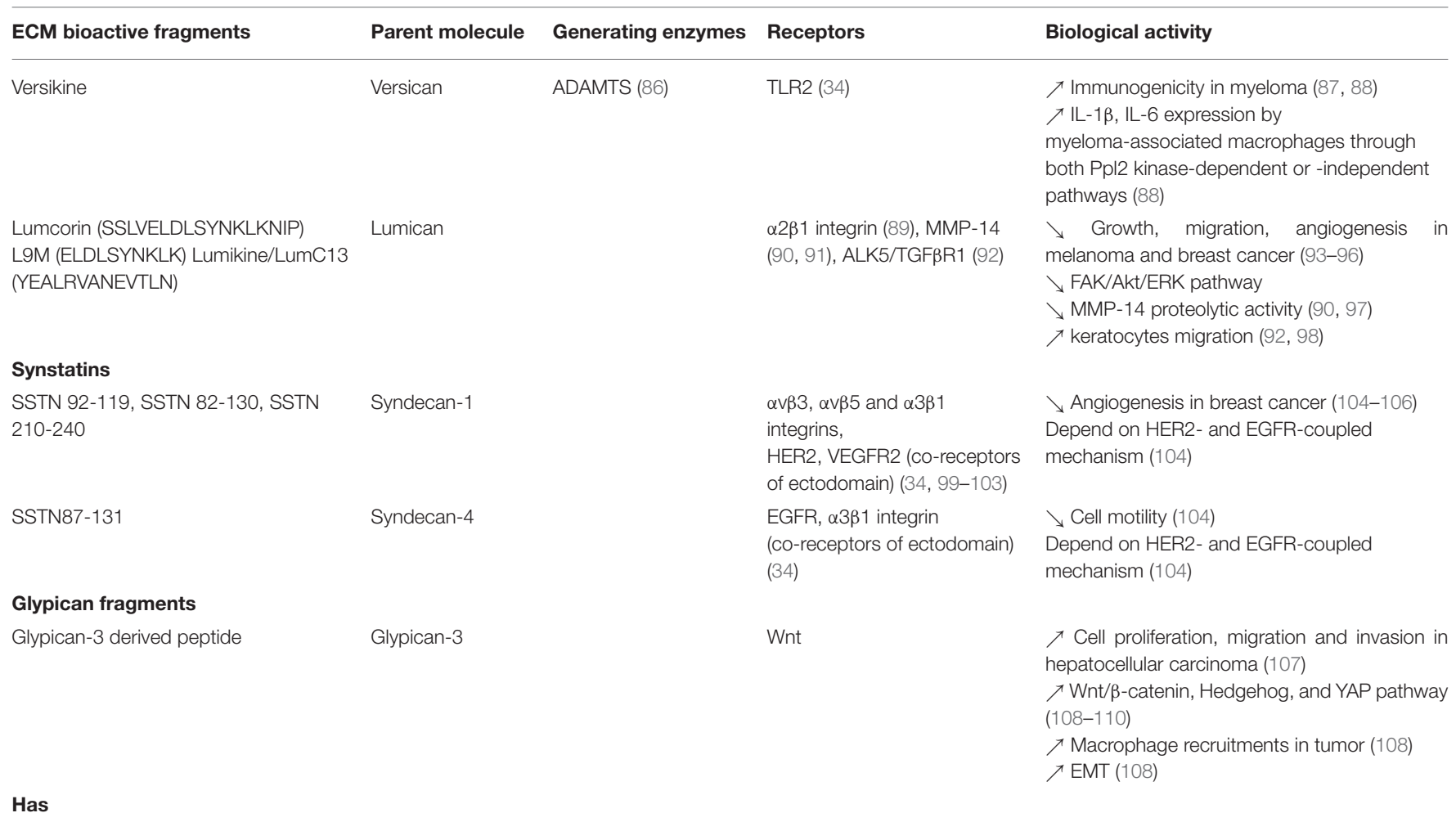

HA oligosaccharides HA CD44 (111)

Alters tumor growth, metastatic potential, and progression in prostate, colon, breast, and endometrial cancers $(112,113,165)$ LMW HA promotes angiogenesis (114) HMW HA decreases angiogenesis, induces EMT (114)

\begin{abstract}
4E-BP1 protein, eukaryotic initiation factor 4E-binding protein 1; ADAMTS, a disintegrin and metalloproteinase with thrombospondin motifs; AP-1, activator protein 1; ATF, activating transcription factor; ALK5, TGFB type I receptor kinase; BMP, bone morphogenetic protein; CGMP, cyclic guanosine monophosphate; EC, endothelial cell; ECM, extracellular matrix; EGFR, epidermal growth factor receptor; EMT, epithelial-mesenchymal transition; ERC, elastin receptor complex; ERK, extracellular signal-regulated kinase; FAK, focal adhesion kinase; HA, hyaluronan; HER2, human epidermal growth factor receptor-2; HMW-HA, high-molecular-weight HA; IL, interleukin; JAG2, jagged canonical Notch ligand 2; LMW-HA, low-molecularweight HA; MAPK, mitogen-activated protein kinase; MEK, MAPK/ERK kinase; MMP, matrix metalloproteinase; $m T L D$, mammalian Tolloid; mTOR, mammalian target of rapamycin; NF, nuclear factor; NO, nitric oxide; PI3K, phosphoinositide 3-kinase; RPSA, ribosomal protein SA; TLR, Toll-like receptor; t-PA, tissue-type plasminogen activator; uPA, urokinase-type plasminogen activator; VEGF, vascular endothelial growth factor; VEGFR, vascular endothelial growth factor tyrosine kinase receptor; TGF $\beta$, transforming growth factor $\beta$.
\end{abstract}

the focal adhesion kinase (FAK)/PI3K/Akt/mTORC1 pathway, which is one of the main intracellular pathways involved in TME metabolic alterations. The inhibition leads to a decrease in the proliferative and invasive properties of tumor cells in various cancer models $(27,33,38,56)$. The main receptors, biological activities, and molecular mechanisms identified for ECM bioactive fragments are reported in Table $\mathbf{1}$ and are illustrated in Figure 2.

\section{EXTRACELLULAR MATRIX FRAGMENTS AS TUMOR BIOMARKERS}

During cancer progression, an excessive ECM remodeling by proteinases, especially MMPs, is observed, and small ECM fragments are released into the circulation. The levels of these fragments may represent a measure of tumor activity and invasiveness and could be proposed as biomarkers (115). Serum and biofluid biomarkers are easy to collect, noninvasive, low cost, and can be followed over the course of the disease. Identification of new biofluid biomarkers may help in early detection, diagnosis, disease monitoring, and in individual treatment selection and thus on patient outcome. However, the low concentrations of ECM-derived fragments in body fluids remain a limitation to the development of these biomarkers in daily practice.

\section{Collagens}

Type I collagen is a major ECM component susceptible to proteinase degradation during cancer progression. Type I collagen cross-linked carboxyterminal telopeptide (ICTP) measurement in patient sera appears to be useful for bone metastasis screening in lung cancer patients, including stage III-IV non-small-cell lung cancer (NSCLC) or extensive disease (ED) small-cell lung cancer (SCLC) (116). ICTP 


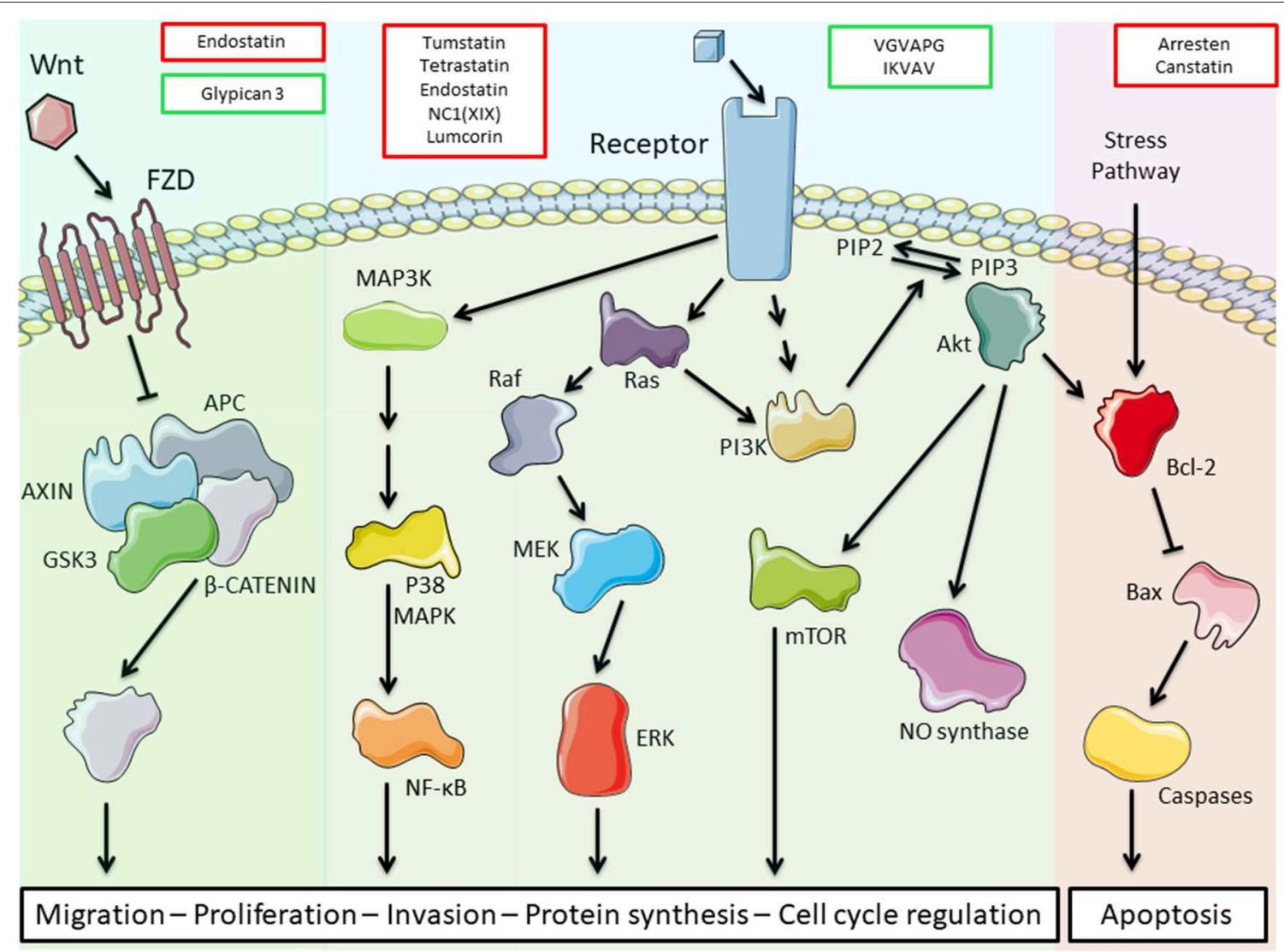

FIGURE 2 | Schematic representation of the main transduction pathways altered by extracellular matrix (ECM) bioactive fragments. Bioactive fragments stimulating the pathway are outlined in green, and fragments with inhibitory activity are outlined in red. Endostatin inhibits the Wnt/ $\beta$-catenin pathway, while glypican- 3 triggers this pathway. Tumstatin, tetrastatin, endostatin, NC1(XIX), and lumcorin inhibit the phosphoinositide 3-kinase (PI3K)/Akt/mammalian target of rapamycin (mTOR) pathway through integrin binding while VGVAPG and IKVAV activate this pathway through elastin receptor complex (ERC) and integrin binding, respectively. VGVAPG and IKVAV also activate the mitogen-activated protein kinase (MAPK) pathways. Arresten and canstatin activate the Bcl-2 pro-apoptotic pathway through integrin binding

level in serum from patients with esophageal squamous cell carcinoma significantly correlates with tumor progression variables, including TNM stages ( $\geq \mathrm{T} 2, \mathrm{~N} 1$, and $\mathrm{M} 1)$, TNM stage $\geq \mathrm{II}$, and maximal tumor length greater than $50 \mathrm{~mm}$ (117). A high level of ICTP in preoperated patient serum appears to be an important marker of better prognosis in triple-negative breast cancer and luminal-B-like [human epidermal growth factor receptor (HER)2-negative] subtypes (118). The elevation of the cross-linked N-telopeptide of type I collagen (NTx) appears positively related with the development and progression of bone metastasis in lung cancer (119). NTx serum concentration may also have a prognostic value in patients with prostate cancer at diagnosis (120). A high level of serum NTx ( $>22 \mathrm{nmol} \mathrm{BCE} / \mathrm{L})$ is correlated with a reduction in overall survival (OS) in patients with NSCLC (121).

In the follow-up of patients with radical resection of colorectal carcinoma, the N-terminal peptide of type III procollagen (marker of ECM synthesis) was reported as an early prognostic indicator of recurrence (122).

The serum level of tumstatin is significantly higher in patients with NSCLC compared to healthy patients (123).
The levels of markers reflecting type I (C1M), type III (C3M), and type IV (C4M, C4M12) collagen degradation by MMPs were significantly elevated in serum of ovarian or breast cancer patients compared to healthy controls (124).

Type VI collagen expression is correlated with various pro-tumorigenic events. Levels of type VI collagen $\alpha 1$ and a3 chain fragments, derived from MMP proteolysis, appear higher in serum from cancer patients (breast, colon, gastric, ovarian, pancreas, prostate cancer, NSCLC, SCLC, melanoma) compared to healthy patients and have promising diagnostic accuracy (125). Type VI collagen $\alpha 3$ chain circulating fragment levels were significantly higher in the serum of pancreatic ductal adenocarcinoma patients compared to healthy patients or patients with benign lesions (126).

Elevated serum endostatin levels were found in various human cancers including colorectal cancer (127), soft tissue sarcoma (128), and advanced-stage nasopharyngeal carcinoma (129). They are correlated with a favorable outcome in acute myeloid leukemia (130). On the contrary, high serum endostatin levels are associated with enhanced ECM degradation and poor patient outcome in patients with bladder cancer (131) and with nonHodgkin lymphoma (132). Determination of soluble vascular 
endothelial growth factor tyrosine kinase receptor (sVEGFR)1 and endostatin levels may be useful in the diagnosis of malignant pleural effusions in patients with lung cancer (133). Preoperative serum VEGF and endostatin levels may be used for evaluating the biological behavior, invasion, and metastasis of gastric, hepatocellular, and colorectal carcinoma (134).

\section{Elastin}

Elastin fragments, released by proteases, are increased in the serum of stage I-IV NSCLC patients compared to healthy controls. These results suggest the use of elastin fragments as potential biomarkers (135), but further validations in clinical trials are needed.

\section{Laminins}

Laminins were reported to promote tumor progression. The serum level of $\mathrm{LN} \gamma 2$ fragments increases according to the $\mathrm{T}$ classification of head and neck squamous cell carcinoma (HNSCC) and decreases after the use of curative treatments. The level of $\mathrm{LN} \gamma 2$ fragments in serum may be useful to predict response to treatment of patients with HNSCC (136). The presence of soluble laminin fragments (ULN) corresponding to the $\mathrm{N}$-terminal domain of the $\beta 2$ chain was measured in urine of healthy subjects and patients with tumor. Mean level of ULN in lung tumor patients is significantly higher than that in healthy subjects (137). Serum laminin P1 fragment was studied in patients with SCLC and NSCLC and in normal subjects. The serum concentration of laminin P1 was elevated in $58.9 \%$ of SCLC and in $11.5 \%$ of NSCLC patients compared to healthy subjects. Median value in SCLC patients was significantly higher than that in NSCLC patients and in normal subjects (138). Urine laminin P1 measurement allows to discriminate between invasive and noninvasive urothelial cell carcinoma of the bladder (139).

\section{Proteoglycans}

The cleavage of proteoglycans like aggrecan and versican by a disintegrin and metalloproteinase with thrombospondin motifs (ADAMTS) in epithelial ovarian cancer has been demonstrated and is considered of prognostic value (75).

Perlecan fragments in the serum of prostate cancer patients were correlated with overall MMP-7 staining levels in prostate cancer tissues. Domain IV fragments of perlecan were highlighted in stage IV patient sera, but not detected in normal patient sera, suggesting that perlecan is degraded during metastasis. The association of perlecan fragments in sera and MMP-7 expression in tissues reflects prostate cancer invasivity (77). In breast cancer, the level of the endorepellin LG3 fragment in serum was significantly lower in breast cancer patients compared to healthy subjects. This suggests the endorepellin LG3 fragment as a new potential serological biomarker in breast cancer (140).

NSCLC patients presenting tumors with a low concentration of sulfated glycosaminoglycans (GAG) and high proteoglycan (PGs) levels presented better overall survival compared to patients with a high concentration of sulfated GAG and low expression of proteoglycans. These data suggest that matrix PGs could be considered as biomarkers in lung cancer (141).
Versican has been shown to be a potential biomarker in different cancers such as hepatocellular carcinoma (142), colon cancer (143), and recently in ovarian cancer (144). Hope et al. (145) provide a rational for testing versican proteolysis as a predictive and/or prognostic immune biomarker.

Lumcorin, a lumican-derived peptide mimics the inhibitory effect of lumican in melanoma progression (97). Lumikine, another lumican-derived peptide, promotes the healing of corneal epithelium debridement (92). These peptides might be putative cancer biomarkers but, to our knowledge, there are up to now no data in the literature describing lumican-derived peptides as biological markers in cancer.

Syndecan-1 was reported to play an immunomodulatory function in the polarization of $\mathrm{CD}^{+}{ }^{+} \mathrm{T}$ helper (Th) cells that were isolated from the TME of inflammatory breast cancer (IBC) and non-IBC patients (99). These results suggest that syndecan-1 expression in tumor could offer therapeutic potential in breast cancer. Remarkably, syndecan-1 seems to be overexpressed in inflammatory breast cancer, making it a potential biomarker.

New biomarkers such as syndecan-2 gene methylation (with improved detection sensitivity and specificity at lower costs) should lead to a great improvement in colorectal cancer screening. Syndecan-2 gene methylation was reported as a frequent event in precancerous lesions and appears detectable in bowel lavage fluid to identify patients with colorectal cancer $(146,147)$.

Syndecan-3- and aggrecan-peptides were recently described as novel biomarkers for the detection of epithelial ovarian cancer (144).

Syndecan-1 and syndecan-4 are described as independent indicators in breast carcinomas (148). Peptides based on interaction motifs in syndecan-1 and syndecan-4, named synstatins or SSTN peptides, are potential therapeutic agents for carcinomas depending on the HER2 and epidermal growth factor receptor (EGFR) pathway for their invasion and survival (104).

Glypican-1 detected in exosomes was suggested as a putative biomarker for early detection of pancreatic (149-154) and colorectal cancer $(155,156)$.

Glypican-3 is an important player in the Wnt, Hedgehog, and YAP signaling cascades involved in cancer cell proliferation and migration $(108,109)$. It is overexpressed in hepatocarcinoma and lung carcinoma and was reported as a poor prognosis marker in hepatocarcinoma. Glypican-3 represents a promising immunotherapeutic target. Different GPC3-targeting therapies have been developed: the use of humanized anti-GPC3 cytotoxic antibodies, the treatment with peptide/DNA vaccines, immunotoxin therapies, and genetic therapies (107, 157-162).

The involvement of CD44 and hyaluronan (HA) and the interaction of both molecules were demonstrated in numerous cancers (Table 1) and suggest their potential as biomarkers. HA molecules may exert distinct effects depending on their size and concentration. High-molecular-weight HAs (HMW HAs) are involved in cell proliferation and tissue development, whereas low-molecular-weight HAs (LMW HAs) enhance angiogenesis. Serum level of LMW HA in patients with breast cancer was correlated with lymph node metastasis, and LMW HA was suggested as a cancer biomarker (114). An increase in HA levels 
induces tumor growth in mice and is associated with poor prognosis in pancreatic ductal adenocarcinoma (PDAC) patients. The inhibition of HA synthesis/signaling or the depletion of HA in tumor stroma may be a promising therapeutic approach to fight against PDAC progression (112). HA was also reported to facilitate cell proliferation and invasiveness in malignant pleural mesothelioma (163) and in melanoma (164) and may be used as a biomarker for early diagnosis and management of these diseases (163-165).

\section{CONCLUSION}

ECM fragments evidenced peripheral tissue proteolysis by cancer cells and could control cancer progression by exerting both anti-angiogenic and anti-tumorigenic properties. We showed that ECM-derived bioactive fragments are able to inhibit major transduction pathways involved in TME alterations, such as the FAK/PI3K/Akt/mTORC1 pathway (Figure 2). They represent potent antitumor agents that might be useful in combination with conventional chemo-, immune-, and targeted therapies as part of personalized medicine. Moreover, they diffuse into the body

\section{REFERENCES}

1. Joyce JA, Pollard JW. Microenvironmental regulation of metastasis. Nat Rev Cancer. (2009) 9:239-52. doi: 10.1038/nrc2618

2. Quail DF, Joyce JA. Microenvironmental regulation of tumor progression and metastasis. Nat Med. (2013) 19:1423-37. doi: 10.1038/nm.3394

3. Gregory AD, Houghton AM. Tumor-associated neutrophils: new targets for cancer therapy. Cancer Res. (2011) 71:24116. doi: 10.1158/0008-5472.CAN-10-2583

4. Kalluri R. The biology and function of fibroblasts in cancer. Nat Rev Cancer. (2016) 16:582-98. doi: 10.1038/nrc.2016.73

5. Martin M, Wei H, Lu T. Targeting microenvironment in cancer therapeutics. Oncotarget. (2016) 7:52575-83. doi: 10.18632/oncotarget.9824

6. Joyce JA. Therapeutic targeting of the tumor microenvironment. Cancer Cell. (2005) 7:513-20. doi: 10.1016/j.ccr.2005.05.024

7. Santi A, Kugeratski FG, Zanivan S. Cancer associated fibroblasts: the architects of stroma remodeling. Proteomics. (2018) 18:e1700167. doi: 10.1002/pmic.201700167

8. Saggar JK, Yu M, Tan Q, Tannock IF. The tumor microenvironment and strategies to improve drug distribution. Front Oncol. (2013) 3:154. doi: 10.3389/fonc.2013.00154

9. Laitala A, Erler JT. Hypoxic signalling in tumour stroma. Front Oncol. (2018) 8:189. doi: 10.3389/fonc.2018.00189

10. Griselda de la Cruz Lopezi K, Esperanza Toledo Guzman M, Ortiz Sanchez E, Garcia Carranca A. mTORC1 as regulator of mitochondrial functions and a therapeutic target in cancer. Front Oncol. (2019) 9:1373. doi: 10.3389/fonc.2019.01373

11. Escoté X, Fajas L. Metabolic adaptation to cancer growth: From the cell to the organism. Cancer Lett. (2015) 356:171-5. doi: 10.1016/j.canlet.2014.03.034

12. Lyssiotis CA, Kimmelman AC. Metabolic interactions in the tumor microenvironment. Trends Cell Biol. (2017) 27:86375. doi: $10.1016 /$ j.tcb.2017.06.003

13. Monboisse JC, Gardès-Albert M, Randoux A, Borel JP, Ferradini C. Collagen degradation by superoxide anion in pulse and gamma radiolysis. BBA Gen Subj. (1988) 965:29-35. doi: 10.1016/0304-4165(88)90147-X

14. Socovich AM, Naba A. The cancer matrisome: From comprehensive characterization to biomarker discovery. Semin Cell Dev Biol. (2019) 89:15766. doi: 10.1016/j.semcdb.2018.06.005 and are easy to measure in the blood or body fluids and thus can represent valuable markers for the diagnosis and prognosis of numerous cancers.

\section{AUTHOR CONTRIBUTIONS}

SB-P, SB, BB, and JM contributed to manuscript writing. $\mathrm{LR}$ and $\mathrm{J}-\mathrm{BO}$ contributed to manuscript revision. J-BO designed Figure 2. All authors approved the final version of the manuscript.

\section{FUNDING}

This work was supported by the Centre National de la Recherche Scientifique (UMR 7369), the University of Reims ChampagneArdenne, and the Region Grand-Est.

\section{ACKNOWLEDGMENTS}

The authors thank R. Rivet for his helpful contribution in bibliography.

15. Grahovac J, Wells A. Matrikine and matricellular regulators of EGF receptor signaling on cancer cell migration and invasion. Lab Investig. (2014) 94:3140. doi: 10.1038/labinvest.2013.132

16. Emon B, Bauer J, Jain Y, Jung B, Saif T. Biophysics of tumor microenvironment and cancer metastasis - a mini review. Comput Struct Biotechnol J. (2018) 16:279-87. doi: 10.1016/j.csbj.2018.07.003

17. Eble JA, Niland S. The extracellular matrix in tumor progression and metastasis. Clin Exp Metastasis. (2019) 36:17198. doi: 10.1007/s10585-019-09966-1

18. Balkwill FR, Capasso M, Hagemann T. The tumor microenvironment at a glance. J Cell Sci. (2012) 125:5591-6. doi: 10.1242/jcs.116392

19. Levental KR, Yu H, Kass L, Lakins JN, Egeblad M, Erler JT, et al. Matrix crosslinking forces tumor progression by enhancing integrin signaling. Cell. (2009) 139:891-906. doi: 10.1016/j.cell.2009.10.027

20. Fernandes RJ, Hirohata S, Engle JM, Colige A, Cohn DH, Eyre DR, et al. Procollagen II amino propeptide processing by ADAMTS-3. J Biol Chem. (2001) 120:453-65. doi: 10.1074/jbc.M103466200

21. Wang Z, Bryan J, Franz C, Havlioglu N, Sandell LJ. Type IIB procollagen NH2-propeptide induces death of tumor cells via interaction with integrins $\alpha \mathrm{v} \beta 3$ and $\alpha \mathrm{v} \beta 5$. J Biol Chem. (2010) 285:20806-17. doi: 10.1074/jbc.M110.118521

22. Sandell LJ. Novel functions for Type II procollagen. Connect Tissue Res. (2014) 55:20-5. doi: 10.3109/03008207.2013.867340

23. Sugiyama A, Mitsui A, Okada M, Yamawaki H. Cathepsin S degrades arresten and canstatin in infarcted area after myocardial infarction in rats. J Vet Med Sci. (2019) 103:1562-70. doi: 10.1292/jvms.18-0674

24. Rebustini IT, Myers C, Lassiter KS, Surmak A, Szabova L, Holmbeck K, et al. MT2-MMP-dependent release of collagen IV NC1 domains regulates submandibular gland branching morphogenesis. Dev Cell. (2009) 40:158196. doi: 10.1016/j.devcel.2009.07.016

25. Aikio M, Alahuhta I, Nurmenniemi S, Suojanen J, Palovuori R, Teppo S, et al. Arresten, a collagen-derived angiogenesis inhibitor, suppresses invasion of squamous cell carcinoma. PLoS ONE. (2012) 7:e51044. doi: 10.1371/journal.pone.0051044

26. Sudhakar A, Nyberg P, Keshamouni VG, Mannam AP, Li J, Sugimoto $\mathrm{H}$, et al. Human $\alpha 1$ type IV collagen $\mathrm{NC1}$ domain exhibits distinct antiangiogenic activity mediated by $\alpha 1 \beta 1$ integrin. J Clin Invest. (2005) 317:2562-72. doi: 10.1172/JCI24813 
27. Magnon C, Galaup A, Mullan B, Rouffiac V, Bidart JM, Griscelli F, et al. Canstatin acts on endothelial and tumor cells via mitochondrial damage initiated through interaction with $\alpha v \beta 3$ and $\alpha v \beta 5$ integrins. Cancer Res. (2005) 8:9837. doi: 10.1158/0008-5472.CAN-04-3536

28. Okada M, Yamawaki H. A current perspective of canstatin, a fragment of type IV collagen alpha 2 chain. J Pharmacol Sci. (2019) 7:12234. doi: 10.1016/j.jphs.2018.12.001

29. Hwang-Bo J, Park JH, Bae MG, Chung IS. Recombinant canstatin inhibits VEGF-A-induced lymphangiogenesis and metastasis in an oral squamous cell carcinoma SCC-VII animal model. Cancer Med. (2016) 5:297788. doi: $10.1002 /$ cam 4.866

30. Xing YN, Deng P, Xu HM. Canstatin induces apoptosis in gastric cancer xenograft growth in mice through the mitochondrial apoptotic pathway. Biosci Rep. (2014) 7:255-65. doi: 10.1042/BSR20140012

31. Hamano Y, Zeisberg M, Sugimoto H, Lively JC, Maeshima Y, Yang C, et al. Physiological levels of tumstatin, a fragment of collagen IV $\alpha 3$ chain, are generated by MMP-9 proteolysis and suppress angiogenesis via $\alpha \mathrm{V} \beta 3$ integrin. Cancer Cell. (2003) 28:101-9. doi: 10.1016/S1535-6108(03)00133-8

32. Pedchenko V, Zent R, Hudson BG. $\alpha$ v $\beta 3$ and $\alpha v \beta 5$ integrins bind both the proximal RGD site and non-RGD motifs within noncollagenous (NC1) domain of the $\alpha 3$ chain of type IV collagen: Implication for the mechanism of endothelial cell adhesion. J Biol Chem. (2004) 61:10228. doi: 10.1074/jbc.M311901200

33. Monboisse JC, Oudart JB, Ramont L, Brassart-Pasco S, Maquart FX. Matrikines from basement membrane collagens: a new anti-cancer strategy. Biochim Biophys Acta Gen Subj. (2014) 1840:2589-98. doi: 10.1016/j.bbagen.2013.12.029

34. Ricard-Blum S, Vallet SD. Fragments generated upon extracellular matrix remodeling: Biological regulators and potential drugs. Matrix Biol. (2019) 57-8:285-98. doi: 10.1016/j.matbio.2017.11.005

35. Maeshima Y, Colorado PC, Kalluri R. Two RGD-independent $\alpha(v) \beta 3$ integrin binding sites on tumstatin regulate distinct anti-tumor properties. J Biol Chem. (2000) 56:381-91. doi: 10.1074/jbc.C000186200

36. Floquet N, Pasco S, Ramont L, Derreumaux P, Laronze JY, Nuzillard JM, et al. The antitumor properties of the $\alpha 3$ (IV)-(185-203) peptide from the NC1 domain of type IV collagen (Tumstatin) are conformation-dependent. J Biol Chem. (2004) 278:4238-49. doi: 10.1074/jbc.M307736200

37. Brassart-Pasco S, Sénéchal K, Thevenard J, Ramont L, Devy J, Di Stefano L, et al. Tetrastatin, the NC1 domain of the $\alpha 4$ (IV) collagen chain: A novel potent anti-tumor matrikine. PLoS ONE. (2012) 7:e29587. doi: 10.1371/journal.pone.0029587

38. Lambert E, Fuselier E, Ramont L, Brassart B, Dukic S, Oudart JB, et al. Conformation-dependent binding of a Tetrastatin peptide to $\alpha v \beta 3$ integrin decreases melanoma progression through FAK/PI3K/Akt pathway inhibition. Sci Rep. (2018) 6:30599. doi: 10.1038/s41598-018-28003-x

39. Pasco S, Ramont L, Venteo L, Pluot M, Maquart FX, Monboisse JC. In vivo overexpression of tumstatin domains by tumor cells inhibits their invasive properties in a mouse melanoma model. Exp Cell Res. (2004) 301:25165. doi: 10.1016/j.yexcr.2004.07.036

40. Thevenard J, Floquet N, Ramont L, Prost E, Nuzillard JM, Dauchez $M$, et al. Structural and antitumor properties of the YSNSG cyclopeptide derived from tumstatin. Chem Biol. (2006) 13:1307-15. doi: 10.1016/j.chembiol.2006.10.007

41. Karagiannis ED, Popel AS. Identification of novel short peptides derived from the $\alpha 4, \alpha 5$, and $\alpha 6$ fibrils of type IV collagen with antiangiogenic properties. Biochem Biophys Res Commun. (2007) 17:68798. doi: 10.1016/j.bbrc.2006.12.231

42. Weckmann M, Moir LM, Heckman CA, Black JL, Oliver BG, Burgess JK. Lamstatin - a novel inhibitor of lymphangiogenesis derived from collagen IV. J Cell Mol Med. (2012) 35:34-41. doi: 10.1111/j.1582-4934.2012.01648.x

43. Koskimaki JE, Karagiannis ED, Tang BC, Hammers H, Watkins DN, Pili R, et al. Pentastatin-1, a collagen IV derived 20-mer peptide, suppresses tumor growth in a small cell lung cancer xenograft model. BMC Cancer. (2010) 128:680-5. doi: 10.1186/1471-2407-10-29

44. Mundel TM, Yliniemi AM, Maeshima Y, Sugimoto H, Kieran M, Kalluri R. Type IV collagen $\alpha 6$ chain-derived noncollagenous domain $1(\alpha 6(\mathrm{IV}) \mathrm{NC} 1)$ inhibits angiogenesis and tumor growth. Int J Cancer. (2008) 122:173844. doi: $10.1002 /$ ijc. 23269
45. Li Y, Li J, Woo YM, Shen Z, Yao H, Cai Y, et al. Enhanced expression of Vastatin inhibits angiogenesis and prolongs survival in murine orthotopic glioblastoma model. BMC Cancer. (2017) 588:431924. doi: 10.1186/s12885-017-3125-8

46. Shen Z, Yao C, Wang Z, Yue L, Fang Z, Yao H, et al. Vastatin, an endogenous antiangiogenesis polypeptide that is lost in hepatocellular carcinoma, effectively inhibits tumor metastasis. Mol Ther. (2016) 75-6:27185. doi: $10.1038 / \mathrm{mt} .2016 .56$

47. Ramchandran R, Dhanabal M, Volk R, Waterman MJF, Segal M, Lu H, et al. Antiangiogenic activity of restin, NC10 domain of human collagen XV: Comparison to endostatin. Biochem Biophys Res Commun. (1999) 118:9152232. doi: 10.1006/bbrc.1999.0248

48. Lu Z, Jiao D, Qiao J, Yang S, Yan M, Cui S, et al. Restin suppressed epithelialmesenchymal transition and tumor metastasis in breast cancer cells through upregulating mir-200a/b expression via association with p73. Mol Cancer. (2015) 62:125-33. doi: 10.1186/s12943-015-0370-9

49. Wu Y, Lu F, Qi Y, Wang R, Zhang J, Lu Z, et al. Interaction of Restin with transcription factors. Sci China Ser C Life Sci. (2005) 8:e82730. doi: 10.1360/04yc0073

50. Wickström SA, Alitalo K, Keski-Oja J. Endostatin associates with integrin alpha5betal and caveolin-1, and activates Src via a tyrosyl phosphatasedependent pathway in human endothelial cells. Cancer Res. (2002) 62:5580-9.

51. Walia A, Yang JF, Huang YH, Rosenblatt MI, Chang JH, Azar DT. Endostatin's emerging roles in angiogenesis, lymphangiogenesis, disease, and clinical applications. Biochim Biophys Acta Gen Subj. (2015) 280:2194206. doi: 10.1016/j.bbagen.2015.09.007

52. Digtyar AV, Pozdnyakova NV, Feldman NB, Lutsenko SV, Severin SE. Endostatin: current concepts about its biological role and mechanisms of action. Biochem. (2007) 132:235-246. doi: 10.1134/S00062979070 30017

53. Hamano Y, Kalluri R. Tumstatin, the NC1 domain of $\alpha 3$ chain of type IV collagen, is an endogenous inhibitor of pathological angiogenesis and suppresses tumor growth. Biochem Biophys Res Commun. (2005) 652:508. doi: 10.1016/j.bbrc.2005.05.130

54. Hendaoui I, Lavergne E, Lee HS, Hong SH, Kim HZ, Parent C, et al. Inhibition of Wnt/ $\beta$-Catenin signaling by a soluble Collagen-Derived frizzled domain interacting with Wnt3a and the receptors frizzled 1 and 8. PLoS ONE. (2012) 7:e30601. doi: 10.1371/journal.pone.0030601

55. Oudart JB, Brassart-Pasco S, Vautrin A, Sellier C, Machado C, Dupont-Deshorgue A, et al. Plasmin releases the anti-tumor peptide from the NC1 domain of collagen XIX. Oncotarget. (2015) 5:e202. doi: 10.18632/oncotarget.2849

56. Oudart JB, Doué M, Vautrin A, Brassart B, Sellier C, Dupont-Deshorgue $A$, et al. The anti-tumor $\mathrm{NC1}$ domain of collagen XIX inhibits the FAK/PI3K/Akt/mTOR signaling pathway through $\alpha v \beta 3$ integrin interaction. Oncotarget. (2016) 41:1010428319847081. doi: 10.18632/oncotarget.6399

57. Oudart JB, Monboisse JC, Maquart FX, Brassart B, Brassart-Pasco S, Ramont L. Type XIX collagen: a new partner in the interactions between tumor cells and their microenvironment. Matrix Biol. (2017) 13:34761. doi: 10.1016/j.matbio.2016.07.010

58. Heinz A, Jung MC, Jahreis G, Rusciani A, Duca L, Debelle L, et al. The action of neutrophil serine proteases on elastin and its precursor. Biochimie. (2012) 2015:563818. doi: 10.1016/j.biochi.2011.10.006

59. Heinz A, Jung MC, Duca L, Sippl W, Taddese S, Ihling C, et al. Degradation of tropoelastin by matrix metalloproteinases - Cleavage site specificities and release of matrikines. FEBS J. (2010) 277:193956. doi: 10.1111/j.1742-4658.2010.07616.x

60. Mora Huertas AC, Schmelzer CEH, Luise C, Sippl W, Pietzsch M, Hoehenwarter W, et al. Degradation of tropoelastin and skin elastin by neprilysin. Biochimie. (2018) 146:73-8. doi: 10.1016/j.biochi.2017.11.018

61. Pocza P, Süli-Vargha H, Darvas Z, Falus A. Locally generated VGVAPG and VAPG elastin-derived peptides amplify melanoma invasion via the galectin-3 receptor. Int J Cancer. (2008) 122:1972-80. doi: 10.1002/ijc.23296

62. Brassart B, Da Silva J, Donet M, Seurat E, Hague F, Terryn C, et al. Tumour cell blebbing and extracellular vesicle shedding: key role of matrikines and ribosomal protein SA. Br J Cancer. (2019) 120:45365. doi: 10.1038/s41416-019-0382-0 
63. Robinet A, Fahem A, Cauchard J-H, Huet E, Vincent L, Lorimier S, et al. Elastin-derived peptides enhance angiogenesis by promoting endothelial cell migration and tubulogenesis through upregulation of MT1-MMP. J Cell Sci. (2005) 118:343-56. doi: 10.1242/jcs.01613

64. Ntayi C, Labrousse AL, Debret R, Birembaut P, Bellon G, Antonicelli F, et al. Elastin-derived peptides upregulate matrix metalloproteinase-2-ediated melanoma cell invasion through elastin-binding protein. J Invest Dermatol. (2004) 122:256-65. doi: 10.1046/j.0022-202X.2004.22228.x

65. Devy J, Duca L, Cantarelli B, Joseph-Pietras D, Scandolera A, Rusciani $\mathrm{A}$, et al. Elastin-derived peptides enhance melanoma growth in vivo by upregulating the activation of Mcol-A (MMP-1) collagenase. Br J Cancer. (2010) 103:1562-70. doi: 10.1038/sj.bjc.6605926

66. Fahem A, Robinet A, Cauchard JH, Duca L, Soula-Rothhut M, Rothhut B, et al. Elastokine-mediated up-regulation of MT1-MMP is triggered by nitric oxide in endothelial cells. Int J Biochem Cell Biol. (2008) 40:158196. doi: 10.1016/j.biocel.2007.11.022

67. Debret R, Le Naour RR, Sallenave JM, Deshorgue A, Hornebeck WG, Guenounou $M$, et al. Elastin fragments induce IL-1 $\beta$ upregulation via NF-кB pathway in melanoma cells. J Invest Dermatol. (2006) 126:18608. doi: 10.1038/sj.jid.5700337

68. Kikkawa Y, Hozumi K, Katagiri F, Nomizu M, Kleinman HK, Koblinski JE. Laminin-111-derived peptides and cancer. Cell Adhes Migr. (2013) 7:1509. doi: $10.4161 / \mathrm{cam} .22827$

69. Li B, Qiu T, Zhang P, Wang X, Yin Y, Li S. IKVAV regulates ERK1/2 and Akt signalling pathways in BMMSC population growth and proliferation. Cell Prolif. (2014) 47:133-45. doi: 10.1111/cpr.12094

70. Nascimento CF, de Siqueira AS, Pinheiro JJV, Freitas VM, Jaeger RG. Laminin-111 derived peptides AG73 and C16 regulate invadopodia activity of a human adenoid cystic carcinoma cell line. Exp Cell Res. (2011) 317:256272. doi: 10.1016/j.yexcr.2011.08.022

71. Rousselle P, Beck K. Laminin 332 processing impacts cellular behavior. Cell Adhes Migr. (2013) 7:122-34. doi: 10.4161/cam.23132

72. Kusuma N, Anderson RL, Pouliot N. Laminin $\alpha 5$-derived peptides modulate the properties of metastatic breast tumour cells. Clin Exp Metastasis. (2011) 28:909-21. doi: 10.1007/s10585-011-9422-8

73. Ambesi A, McKeown-Longo PJ. Anastellin, the angiostatic fibronectin peptide, is a selective inhibitor of lysophospholipid signaling. Mol Cancer Res. (2009) 7:255-65. doi: 10.1158/1541-7786.MCR-08-0195

74. You R, Klein RM, Zheng M, McKeown-Longo PJ. Regulation of p38 MAP kinase by anastellin is independent of anastellin's effect on matrix fibronectin. Matrix Biol. (2009) 28:101-9. doi: 10.1016/j.matbio.2009.01.003

75. Lima MA, Dos Santos L, Turri JA, Nonogaki S, Buim M, Lima JF, et al. Prognostic value of ADAMTS proteases and their substrates in epithelial ovarian cancer. Pathobiology. (2016) 12:508-15. doi: 10.1159/000446244

76. Liu N, Lapcevich RK, Underhill CB, Han Z, Gao F, Swartz G, et al. Metastatin: a hyaluronan-binding complex from cartilage that inhibits tumor growth. Cancer Res. (2001) 61:1022-8.

77. Grindel B, Li Q, Arnold R, Petros J, Zayzafoon M, Muldoon M, et al. Perlecan/HSPG2 and matrilysin/MMP-7 as indices of tissue invasion: Tissue localization and circulating perlecan fragments in a cohort of 288 radical prostatectomy patients. Oncotarget. (2016) 59:61529. doi: 10.18632/oncotarget.11976

78. Gubbiotti MA, Neill T, Iozzo RV. A current view of perlecan in physiology and pathology: a mosaic of functions. Matrix Biol. (2017) 57-8:28598. doi: 10.1016/j.matbio.2016.09.003

79. Douglass S, Goyal A, Iozzo RV. The role of perlecan and endorepellin in the control of tumor angiogenesis and endothelial cell autophagy. Connect Tissue Res. (2015) 56:381-91. doi: 10.3109/03008207.2015.1045297

80. Mongiat M, Sweeney SM, San Antonio JD, Fu J, Iozzo RV. Endorepellin, a novel inhibitor of angiogenesis derived from the $\mathrm{C}$ terminus of perlecan. J Biol Chem. (2003) 278:4238-49. doi: 10.1074/jbc.M21044 5200

81. Le BV, Kim H, Choi J, Kim JH, Hahn MJ, Lee C, et al. Crystal structure of the LG3 domain of endorepellin, an angiogenesis inhibitor. J Mol Biol. (2011) 414:231-42. doi: 10.1016/j.jmb.2011.09.048

82. Goyal A, Gubbiotti MA, Chery DR, Han L, Iozzo RV. Endorepellinevoked autophagy contributes to angiostasis. J Biol Chem. (2016) 291:1924556. doi: 10.1074/jbc.M116.740266
83. Poluzzi C, Iozzo RV, Schaefer L. Endostatin and endorepellin: a common route of action for similar angiostatic cancer avengers. Adv Drug Deliv Rev. (2016) 97:156-73. doi: 10.1016/j.addr.2015.10.012

84. Gubbiotti MA, Iozzo RV. Proteoglycans regulate autophagy via outsidein signaling: an emerging new concept. Matrix Biol. (2015) 48:613. doi: $10.1016 /$ j.matbio.2015.10.002

85. Neill T, Andreuzzi E, Wang ZX, Peiper SC, Mongiat M, Iozzo RV. Endorepellin remodels the endothelial transcriptome toward a proautophagic and pro-mitophagic gene signature. J Biol Chem. (2018) 293:12137-48. doi: 10.1074/jbc.RA118.002934

86. McCulloch DR, Nelson CM, Dixon LJ, Silver DL, Wylie JD, Lindner $\mathrm{V}$, et al. ADAMTS metalloproteases generate active versican fragments that regulate interdigital web regression. Dev Cell. (2009) 17:68798. doi: 10.1016/j.devcel.2009.09.008

87. Nandadasa S, Foulcer S, Apte SS. The multiple, complex roles of versican and its proteolytic turnover by ADAMTS proteases during embryogenesis. Matrix Biol. (2014) 35:34-41. doi: 10.1016/j.matbio.2014.01.005

88. Hope C, Foulcer S, Jagodinsky J, Chen SX, Jensen JL, Patel $\mathrm{S}$, et al. Immunoregulatory roles of versican proteolysis in the myeloma microenvironment. Blood. (2016) 128:6805. doi: 10.1182/blood-2016-03-705780

89. Zeltz C, Brézillon S, Käpylä J, Eble JA, Bobichon H, Terryn C, et al. Lumican inhibits cell migration through $\alpha 2$ ? 1 integrin. Exp Cell Res. (2010) 316:292231. doi: 10.1016/j.yexcr.2010.08.002

90. Pietraszek K, Chatron-Colliet A, Brézillon S, Perreau C, JakubiakAugustyn A, Krotkiewski $\mathrm{H}$, et al. Lumican: a new inhibitor of matrix metalloproteinase-14 activity. FEBS Lett. (2014) 588:4319-24. doi: 10.1016/j.febslet.2014.09.040

91. Pietraszek-Gremplewicz K, Karamanou K, Niang A, Dauchez M, Belloy N, Maquart FX, et al. Small leucine-rich proteoglycans and matrix metalloproteinase-14: key partners? Matrix Biol. (2019) 75-6:271-85. doi: 10.1016/j.matbio.2017.12.006

92. Gesteira TF, Coulson-Thomas VJ, Yuan Y, Zhang J, Nader HB, Kao WWY. Lumican peptides: rational design targeting ALK5/TGFBRI. Sci Rep. (2017) 5:e1238542. doi: 10.1038/srep42057

93. Brézillon S, Pietraszek K, Maquart FX, Wegrowski Y. Lumican effects in the control of tumour progression and their links with metalloproteinases and integrins. FEBS J. (2013) 280:2369-81. doi: 10.1111/febs.12210

94. Pietraszek K, Brézillon S, Perreau C, Malicka-Błaszkiewicz M, Maquart FX, Wegrowski Y. Lumican - derived peptides inhibit melanoma cell growth and migration. PLoS ONE. (2013) 8:e76232. doi: 10.1371/journal.pone.00 76232

95. Karamanos NK, Piperigkou Z, Theocharis AD, Watanabe H, Franchi M, Baud S, et al. Proteoglycan chemical diversity drives multifunctional cell regulation and therapeutics. Chem Rev. (2018) 118:9152-232. doi: 10.1021/acs.chemrev.8b00354

96. Karamanou K, Franchi M, Vynios D, Brézillon S. Epithelialto-mesenchymal transition and invadopodia markers in breast cancer: Lumican a key regulator. Semin Cancer Biol. (2019) 62:125-33. doi: 10.1016/j.semcancer.2019.08.003

97. Zeltz C, Brézillon S, Perreau C, Ramont L, Maquart FX, Wegrowski Y. Lumcorin: a leucine-rich repeat 9-derived peptide from human lumican inhibiting melanoma cell migration. FEBS Lett. (2009) 62:63952. doi: 10.1016/j.febslet.2009.08.012

98. Yamanaka O, Yuan Y, Coulson-Thomas VJ, Gesteira TF, Call MK, Zhang Y, et al. Lumican binds ALK5 to promote epithelium wound healing. PLoS ONE. (2013) 8:e82730. doi: 10.1371/journal.pone.0082730

99. Saleh ME, Gadalla R, Hassan H, Afifi A, Götte M, El-Shinawi M, et al. The immunomodulatory role of tumor Syndecan-1 (CD138) on ex vivo tumor microenvironmental $\mathrm{CD} 4+\mathrm{T}$ cell polarization in inflammatory and non-inflammatory breast cancer patients. PLoS ONE. (2019) 18:36863696. doi: 10.1371/journal.pone.0217550

100. Rapraeger AC. Synstatin: a selective inhibitor of the syndecan-1-coupled IGF1R- $\alpha v \beta 3$ integrin complex in tumorigenesis and angiogenesis. FEBS J. (2013) 280:2207-15. doi: 10.1111/febs.12160

101. Rapraeger AC, Ell BJ, Roy M, Li X, Morrison OR, Thomas GM, et al. Vascular endothelial-cadherin stimulates syndecan-1-coupled insulinlike growth factor-1 receptor and cross-talk between $\alpha \mathrm{v} \beta 3$ integrin 
and vascular endothelial growth factor receptor 2 at the onset of endothelial cell dissemination during angiogenesis. FEBS J. (2013) 280:2194206. doi: $10.1111 /$ febs. 12134

102. Jung O, Beauvais DLM, Adams KM, Rapraeger AC. VLA-4 phosphorylation during tumor and immune cell migration relies on its coupling to VEGFR2 and CXCR4 by syndecan-1. J Cell Sci. (2019) 132:jcs232645. doi: 10.1242/jcs. 232645

103. Metwaly HA, El-Gayar AM, El-Shishtawy MM. Inhibition of the signaling pathway of syndecan-1 by synstatin: a promising anti-integrin inhibitor of angiogenesis and proliferation in HCC in rats. Arch Biochem Biophys. (2018) 652:50-8. doi: 10.1016/j.abb.2018.06.007

104. Wang H, Jin H, Rapraeger AC. Syndecan-1 and syndecan-4 capture epidermal growth factor receptor family members and the $\alpha 3 \beta 1$ integrin via binding sites in their ectodomains: novel synstatins prevent kinase capture and inhibit $\alpha 6 \beta 4$-integrindependent epithelial cell motility. J Biol Chem. (2015) 18:58. doi: 10.1074/jbc.M115.679084

105. Beauvais DM, Ell BJ, McWhorter AR, Rapraeger AC. Syndecan-1 regulates $\alpha v \beta 3$ and $\alpha$ v $\beta 5$ integrin activation during angiogenesis and is blocked by synstatin, a novel peptide inhibitor. J Exp Med. (2009) 206:691705. doi: 10.1084/jem.20081278

106. Jung O, Trapp-Stamborski V, Purushothaman A, Jin H, Wang H, Sanderson RD, et al. Heparanase-induced shedding of syndecan1/CD138 in myeloma and endothelial cells activates VEGFR2 and an invasive phenotype: prevention by novel synstatins. Oncogenesis. (2016) 5:e202. doi: 10.1038/oncsis.2016.5

107. Shimizu Y, Suzuki T, Yoshikawa T, Endo I, Nakatsura T. Next-generation cancer immunotherapy targeting glypican-3. Front Oncol. (2019) 57-8:16977. doi: 10.3389/fonc. 2019.00248

108. Zhou F, Shang W, Yu X, Tian J. Glypican-3: a promising biomarker for hepatocellular carcinoma diagnosis and treatment. Med Res Rev. (2018) 13:1307-15. doi: 10.1002/med.21455

109. Li N, Wei L, Liu X, Bai H, Ye Y, Li D, et al. A frizzled-like cysteine-rich domain in glypican-3 mediates Wnt binding and regulates hepatocellular carcinoma tumor growth in mice. Hepatology. (2019) 70:1231-45. doi: 10.1002/hep.30646

110. Kolluri A, Ho M. The role of glypican-3 in regulating Wnt, YAP, and Hedgehog in liver cancer. Front Oncol. (2019) 9:708. doi: 10.3389/fonc.2019.00708

111. Yang C, Cao M, Liu H, He Y, Xu J, Du Y, et al. The high and low molecular weight forms of hyaluronan have distinct effects on CD44 clustering. J Biol Chem. (2012) 287:43094-107. doi: 10.1074/jbc.M112.349209

112. Sato N, Kohi S, Hirata K, Goggins M. Role of hyaluronan in pancreatic cancer biology and therapy: once again in the spotlight. Cancer Sci. (2016) 277:1939-56. doi: 10.1111/cas.12913

113. Adamia S, Pilarski PM, Belch AR, Pilarski LM. Aberrant splicing, Hyaluronan synthases and intracellular Hyaluronan as drivers of oncogenesis and potential drug targets. Curr Cancer Drug Targets. (2013) 13:347-61. doi: 10.2174/1568009611313040001

114. Karousou E, Misra S, Ghatak S, Dobra K, Götte M, Vigetti D, et al. Roles and targeting of the HAS/hyaluronan/CD44 molecular system in cancer. Matrix Biol. (2017) 94:192-202. doi: 10.1016/j.matbio.2016. 10.001

115. Kehlet SN, Sanz-Pamplona R, Brix S, Leeming DJ, Karsdal MA, Moreno V. Excessive collagen turnover products are released during colorectal cancer progression and elevated in serum from metastatic colorectal cancer patients. Sci Rep. (2016) 12:e0187860. doi: 10.1038/srep30599

116. Tang C, Liu Y, Qin H, Li X, Guo W, Li J, et al. Clinical significance of serum BAP, TRACP $5 b$ and ICTP as bone metabolic markers for bone metastasis screening in lung cancer patients. Clin Chim Acta. (2013) 436:316-18. doi: 10.1016/j.cca.2013.09.011

117. Nabeya Y, Shimada H, Okazumi S, Matsubara H, Gunji Y, Suzuki T, et al. Serum cross-linked carboxyterminal telopeptide of type I collagen (ICTP) as a prognostic tumor marker in patients with esophageal squamous cell carcinoma. Cancer. (2002) 94:940-9. doi: 10.1002/cncr. 10267

118. Jääskeläinen A, Jukkola A, Risteli J, Haapasaari KM, Karihtala P. Elevated preoperative serum levels of collagen I carboxyterminal telopeptide predict better outcome in early-stage luminal-B-like (HER2-negative) and triple-negative subtypes of breast cancer. Tumor Biol. (2019) 13:554. doi: 10.1177/1010428319847081

119. Liu B, Zhao Y, Yuan J, Zeng L, Sun R, Meng X, et al. Elevated N-telopeptide as a potential diagnostic marker for bone metastasis in lung cancer: A meta-analysis. PLoS ONE. (2017) 12:693-8. doi: 10.1371/journal.pone.01 87860

120. Jablonka F, Alves B da CA, de Oliveira CGB, Wroclawski ML, Szwarc M, Vitória W de O, et al. Serum crosslinked-N-terminal telopeptide of type I collagen (NTx) has prognostic implications for patients with initial prostate carcinoma (PCa): A pilot study. Clin Chim Acta. (2014) 18:715. doi: 10.1016/j.cca.2014.06.025

121. Tamiya M, Kobayashi M, Morimura O, Yasue T, Nakasuji T, Satomu M, et al. Clinical significance of the serum crosslinked N-telopeptide of type i collagen as a prognostic marker for non-small-cell lung cancer. Clin Lung Cancer. (2013) 111:1605-13. doi: 10.1016/j.cllc.2012.03.012

122. Plebani M, Basso D, Roveroni G, De Paoli M, Galeotti F, Corsini A. N-terminal peptide of type III procollagen: a possible predictor of colorectal carcinoma recurrence. Cancer. (1997) 79:1299303. doi: 10.1002/(SICI)1097-0142(19970401)79:7<1299::AID-CNCR5>3.0.CO;2C

123. Nielsen SH, Willumsen N, Brix S, Sun S, Manon-Jensen T, Karsdal M, et al. Tumstatin, a matrikine derived from collagen type IV $\alpha 3$, is elevated in serum from patients with non-small cell lung cancer. Transl Oncol. (2018) 130:2922-9. doi: 10.1016/j.tranon.2018.02.005

124. Willumsen N, Bager CL, Leeming DJ, Smith V, Karsdal MA, Dornan D, et al. Extracellular matrix specific protein fingerprints measured in serum can separate pancreatic cancer patients from healthy controls. BMC Cancer. (2013) 97:2767-75. doi: 10.1186/1471-2407-13-554

125. Willumsen N, Bager C, Karsdal MA. Matrix metalloprotease generated fragments of type VI collagen have serum biomarker potential in cancer - a proof of concept study. Transl Oncol. (2019) 63:13718. doi: 10.1016/j.tranon.2019.02.004

126. Kang CY, Wang J, Axell-House D, Soni P, Chu ML, Chipitsyna $\mathrm{G}$, et al. Clinical significance of serum COL6A3 in pancreatic ductal adenocarcinoma. J Gastrointest Surg. (2014) 59:18658. doi: 10.1007/s11605-013-2326-y

127. Kantola T, Väyrynen JP, Klintrup K, Mäkelä J, Karppinen SM, Pihlajaniemi T, et al. Serum endostatin levels are elevated in colorectal cancer and correlate with invasion and systemic inflammatory markers. Br J Cancer. (2014) 65:509-14. doi: 10.1038/bjc.2014.456

128. Feldman AL, Pak H, Yang JC, Richard Alexander H, Libutti SK. Serum endostatin levels are elevated in patients with soft tissue sarcoma. Cancer. (2001) 65:60812. doi: 10.1002/1097-0142(20010415)91:8<1525::AID-CNCR1161>3.0. $\mathrm{CO} ; 2-\mathrm{P}$

129. Mo HY, Luo DH, Qiu HZ, Liu H, Chen QY, Tang LQ, et al. Elevated serum endostatin levels are associated with poor survival in patients with advanced-stage nasopharyngeal carcinoma. Clin Oncol. (2013) 25:30817. doi: 10.1016/j.clon.2012.11.009

130. Aref S, El-Sherbiny M, Azmy E, Goda T, Selim T, El-Refaie $\mathrm{M}$, et al. Elevated serum endostatin levels are associated with favorable outcome in acute myeloid leukemia. Hematology. (2008) 2:23-32. doi: 10.1179/102453308X315898

131. Szarvas T, László V, Vom Dorp F, Reis H, Szendröi A, Romics I, et al. Serum endostatin levels correlate with enhanced extracellular matrix degradation and poor patients' prognosis in bladder cancer. Int J Cancer. (2012) 35:23342. doi: $10.1002 /$ ijc. 26343

132. Bono P, Teerenhovi L, Joensuu H. Elevated serum endostatin is associated with poor outcome in patients with non-Hodgkin lymphoma. Cancer. (2003) 15:38-47. doi: 10.1002/cncr.11399

133. Zhu YY, Wu HM, Liu RY. Diagnostic values of sVEGFR-1 and endostatin in malignant pleural effusions in patients with lung cancer. Clin Lab. (2017) 37:878-87. doi: 10.7754/Clin.Lab.2017.170217

134. Li M, Liu FG, Sun P, Gao YJ, Chen HY, Liu HY, et al. Correlations between serum levels of vascular endothelial growth factor and endostatin with clinical pathological characteristics of patients with gastrointestinal cancers. Hepatogastroenterology. (2012) 59:1865-8. doi: 10.5754/hge 10602 
135. Thorlacius-Ussing J, Kehlet SN, Rønnow SR, Karsdal MA, Willumsen N. Non-invasive profiling of protease-specific elastin turnover in lung cancer: biomarker potential. J Cancer Res Clin Oncol. (2019) 199:1933941. doi: 10.1007/s00432-018-2799-x

136. Kuratomi Y, Sato S, Monji M, Shimazu R, Tanaka G, Yokogawa K, et al. Serum concentrations of laminin $\gamma 2$ fragments in patients with head and neck squamous cell carcinoma. Head Neck. (2008) 583:302732. doi: 10.1002/hed.20838

137. Katayama M, Kamihagi K, Hirai S, Kurome T, Murakami K, Hino $\mathrm{F}$, et al. Urinary laminin fragments as a tumour marker potentially reflecting basement membrane destruction. Br J Cancer. (1992) 7:42057. doi: $10.1038 /$ bjc. 1992.105

138. Nakano T, Iwahashi N, Maeda J, Hada T, Higashino K. Serum laminin P1 in small cell lung cancer: a valuable indicator of distant metastasis? $\mathrm{Br} J$ Cancer. (1992) 14:e0217550. doi: 10.1038/bjc.1992.123

139. Abou Farha KMM, Menheere PPCA, Nieman FHM, Janknegt RA, Arends JW. Urine laminin p1 assessment discriminates between invasive and noninvasive urothelial cell carcinoma of the bladder. Urol Int. (1993) 12:47980. doi: $10.1159 / 000282545$

140. Chang JW, Kang UB, Kim DH, Yi JK, Lee JW, Noh DY, et al. Identification of circulating endorepellin LG3 fragment: Potential use as a serological biomarker for breast cancer. Proteomics Clin Appl. (2008) 290:2610313. doi: $10.1002 /$ prca. 200780049

141. Rangel MP, de Sá VK, Prieto T, Martins JRM, Olivieri ER, Carraro D, et al. Biomolecular analysis of matrix proteoglycans as biomarkers in non small cell lung cancer. Glycoconj J. (2018) 35:233-42. doi: 10.1007/s10719-018-9815-x

142. Naboulsi W, Megger DA, Bracht T, Kohl M, Turewicz M, Eisenacher M, et al. Quantitative tissue proteomics analysis reveals versican as potential biomarker for early-stage hepatocellular carcinoma. J Proteome Res. (2016) 4:64. doi: 10.1021/acs.jproteome.5b00420

143. Chida S, Okayama H, Noda M, Saito K, Nakajima T, Aoto K, et al. Stromal VCAN expression as a potential prognostic biomarker for disease recurrence in stage II-III colon cancer. Carcinogenesis. (2016) 9:1900613. doi: $10.1093 /$ carcin/bgw069

144. Kulbe H, Otto R, Darb-Esfahani S, Lammert H, Abobaker S, Welsch G, et al. Discovery and validation of novel biomarkers for detection of epithelial ovarian cancer. Cells. (2019) 21:838-47. doi: 10.1136/ijgc-2019-ESGO.197

145. Hope C, Emmerich PB, Papadas A, Pagenkopf A, Matkowskyj KA, Van De Hey DR, et al. Versican-derived matrikines regulate Batf3-dendritic cell differentiation and promote $\mathrm{T}$ cell infiltration in colorectal cancer. $J$ Immunol. (2017) 38:741-67. doi: 10.4049/jimmunol.1700529

146. Kim JH, Park SC. Syndecan-2 methylation as a new biomarker for early detection of colorectal neoplasm. Gut Liver. (2018) 5:e1129483. doi: 10.5009/gnl18286

147. Park YS, Kim DS, Cho SW, Park JW, Jeon SJ, Moon TJ, et al. Analysis of syndecan-2 methylation in bowel lavage fluid for the detection of colorectal neoplasm. Gut Liver. (2018) 10:85-91. doi: 10.5009/gnl17357

148. Lendorf ME, Manon-Jensen T, Kronqvist P, Multhaupt HAB, Couchman JR. Syndecan-1 and syndecan- 4 are independent indicators in breast carcinoma. J Histochem Cytochem. (2011) 107:569-75. doi: 10.1369/0022155411405057

149. Melo SA, Luecke LB, Kahlert C, Fernandez AF, Gammon ST, Kaye J, et al. Glypican-1 identifies cancer exosomes and detects early pancreatic cancer. Nature. (2015) 523:177-82. doi: 10.1038/nature14581

150. Herreros-Villanueva M, Bujanda L. Glypican-1 in exosomes as biomarker for early detection of pancreatic cancer. Ann Transl Med. (2016) 55:205. doi: 10.3978/j.issn.2305-5839.2015.10.39

151. Lai X, Wang M, McElyea SD, Sherman S, House M, Korc M. A microRNA signature in circulating exosomes is superior to exosomal glypican1 levels for diagnosing pancreatic cancer. Cancer Lett. (2017) 81:52231. doi: 10.1016/j.canlet.2017.02.019

152. Zhou X, Yan T, Huang C, Xu Z, Wang L, Jiang E, et al. Melanoma cell-secreted exosomal miR-155-5p induce proangiogenic switch of cancerassociated fibroblasts via SOCS1/JAK2/STAT3 signaling pathway. J Exp Clin Cancer Res. (2018) 17:482-93. doi: 10.1186/s13046-018-0911-3
153. Frampton AE, Prado MM, López-Jiménez E, Fajardo-Puerta AB, Jawad ZAR, Lawton P, et al. Glypican-1 is enriched in circulating-exosomes in pancreatic cancer and correlates with tumor burden. Oncotarget. (2018) 139:59-64. doi: 10.18632/oncotarget.24873

154. Lu H, Niu F, Liu F, Gao J, Sun Y, Zhao X. Elevated glypican-1 expression is associated with an unfavorable prognosis in pancreatic ductal adenocarcinoma. Cancer Med. (2017) 6:1181-91. doi: 10.1002/ca $\mathrm{m} 4.1064$

155. Li J, Li B, Ren C, Chen Y, Guo X, Zhou L, et al. The clinical significance of circulating GPC1 positive exosomes and its regulative miRNAs in colon cancer patients. Oncotarget. (2017) 8:101189-202. doi: 10.18632/oncotarget.20516

156. Li J, Chen Y, Guo X, Zhou L, Jia Z, Peng Z, et al. GPC1 exosome and its regulatory miRNAs are specific markers for the detection and target therapy of colorectal cancer. J Cell Mol Med. (2017) 21:83847. doi: $10.1111 / \mathrm{jcmm} .12941$

157. Iwama T, Horie K, Yoshikawa T, Nobuoka D, Shimomura M, Sawada $\mathrm{Y}$, et al. Identification of an $\mathrm{H} 2-\mathrm{Kb}$ or $\mathrm{H} 2-\mathrm{Db}$ restricted and glypican-3derived cytotoxic T-lymphocyte epitope peptide. Int J Oncol. (2013) 42:8318. doi: 10.3892/ijo.2013.1793

158. Nobuoka D, Yoshikawa T, Takahashi M, Iwama T, Horie K, Shimomura $\mathrm{M}$, et al. Intratumoral peptide injection enhances tumor cell antigenicity recognized by cytotoxic T lymphocytes: A potential option for improvement in antigen-specific cancer immunotherapy. Cancer Immunol Immunother. (2013) 17:126. doi: 10.1007/s00262-012-1366-6

159. Suzuki S, Sakata J, Utsumi F, Sekiya R, Kajiyama H, Shibata K, et al. Efficacy of glypican-3-derived peptide vaccine therapy on the survival of patients with refractory ovarian clear cell carcinoma. Oncoimmunology. (2016) 14:102. doi: 10.1080/2162402X.2016.1238542

160. Sawada Y, Yoshikawa T, Nobuoka D, Shirakawa H, Kuronuma T, Motomura Y, et al. Phase I trial of a glypican-3-derived peptide vaccine for advanced hepatocellular carcinoma: Immunologic evidence and potential for improving overall survival. Clin Cancer Res. (2012) 48:25662. doi: 10.1158/1078-0432.CCR-11-3044

161. Sawada Y, Yoshikawa T, Ofuji K, Yoshimura M, Tsuchiya N, Takahashi M, et al. Phase II study of the GPC3-derived peptide vaccine as an adjuvant therapy for hepatocellular carcinoma patients. Oncoimmunology. (2016) 5:e1129483. doi: 10.1080/2162402X.2015.1129483

162. Sun Z, Zhu Y, Xia J, Sawakami T, Kokudo N, Zhang N. Status of and prospects for cancer vaccines against hepatocellular carcinoma in clinical trials. Biosci Trends. (2016) 6:3656-68. doi: 10.5582/bst.2015.01128

163. Cortes-Dericks L, Schmid RA. CD44 and its ligand hyaluronan as potential biomarkers in malignant pleural mesothelioma: evidence and perspectives. Respir Res. (2017) 18:58. doi: 10.1186/s12931-017-0546-5

164. Wu RL, Sedlmeier G, Kyjacova L, Schmaus A, Philipp J, Thiele $\mathrm{W}$, et al. Hyaluronic acid-CD44 interactions promote BMP4/7dependent Id $1 / 3$ expression in melanoma cells. Sci Rep. (2018) 122:1972-80. doi: 10.1038/s41598-018-33337-7

165. Cyphert JM, Trempus CS, Garantziotis S. Size matters: molecular weight specificity of hyaluronan effects in cell biology. Int J Cell Biol. (2015) 2015:563818. doi: 10.1155/2015/563818

Conflict of Interest: The authors declare that the research was conducted in the absence of any commercial or financial relationships that could be construed as a potential conflict of interest.

The handling Editor declared a past co-authorship with one of the authors BB.

Copyright (c) 2020 Brassart-Pasco, Brézillon, Brassart, Ramont, Oudart and Monboisse. This is an open-access article distributed under the terms of the Creative Commons Attribution License (CC BY). The use, distribution or reproduction in other forums is permitted, provided the original author(s) and the copyright owner(s) are credited and that the original publication in this journal is cited, in accordance with accepted academic practice. No use, distribution or reproduction is permitted which does not comply with these terms. 